\title{
THE DYNAMICS OF VALUE COMOVEMENT ACROSS GLOBAL EQUITY MARKETS
}

\author{
Mayank Gupta \\ Jan Novotný
}
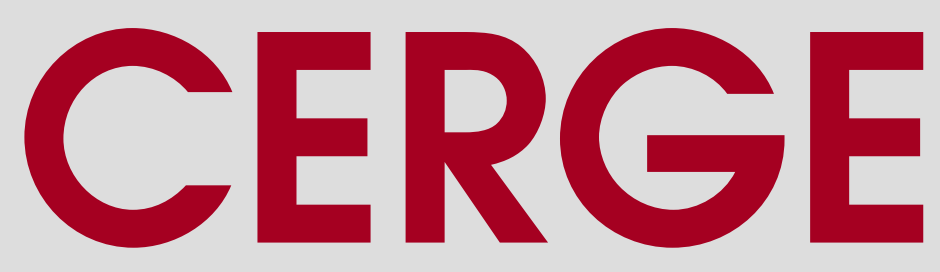

Charles University

Centerfor Economic Research and Graduate Education

Academy of Sciences of the Czech Republic

Ec onomics Institute 


\title{
Working Paper Series $\quad 560$ (ISSN 1211-3298)
}

\section{The Dynamics of Value Comovement across Global Equity Markets}

\author{
Mayank Gupta
}

Jan Novotný

\section{CERGE-EI}

Prague, March 2016 
ISBN 978-80-7343-367-3 (Univerzita Karlova v Praze, Centrum pro ekonomický výzkum a doktorské studium)

ISBN 978-80-7344-373-3 (Národohospodářský ústav AV ČR, v. v. i.) 


\title{
The Dynamics of Value Comovement across Global Equity Markets**
}

\author{
Mayank Gupta ${ }^{\mathrm{a}, *}$, Jan Novotnýb,** \\ ${ }^{a}$ University of Verona, University of Padua, University of Venice Ca' Foscari Italy \\ ${ }^{b}$ Cass Business School, City University London, UK and CERGE-EI, CZ
}

\begin{abstract}
The ratio between share price and current earnings per share, the Price Earning (PE) ratio, is widely considered to be an effective gauge of under/overvaluation of a corporation's stock. Arguably, a more reliable indicator, the Cyclically-Adjusted Price Earning ratio or CAPE, can be obtained by replacing current earnings with a measure of PERMANENT EARNINGS i.e. the profits that a corporation is able to earn, on average, over the medium to long run. In this study, we aim to understand the cross-sectional aspects of the dynamics of the valuation metrics across global stock markets including both developed and emerging markets. We use a time varying DCC model to exploit the dynamics in correlations, by introducing the notion of value spread between CAPE and the respective Market Index from 2002 to 2014 for 34 countries. Value spread is statistically significant during the 2008 crisis for asset allocation. The signal can be utilized for better asset allocation as it allows one to interpret the common movements in the stock market for under/overvaluation trends. These estimates clearly indicate periods of misvaluation in our sample. Furthermore, our simulations suggest that the model can provide early warning signs for asset mispricing in real time on a global scale and formation of asset bubbles.
\end{abstract}

Keywords: Asset Pricing, PE Ratio, CAPE, Price-Earning Ratio, Financial crisis, Value Portfolio, Equity Markets, DCC-GARCH Models.

JEL Classification: C58, G11, G15, G17

${ }^{*}$ Department of Economic Sciences, Faculty of Economics Vicolo Campofiore 2, 37129 Verona (VR) Italy. Mayank.Gupta@univr.it

${ }^{* *}$ Centre for Econometric Analysis, Faculty of Finance, Cass Business School, City University London, 106 Bunhill Row, London, EC1Y 8TZ, UK and CERGE-EI, CZ. Jan.Novotny.1@city.ac.uk, Tel: +44 (0)20 7040 8089, Fax: +44 (0)20 7040 8881. CERGE-EI, a joint workplace of Charles University in Prague and the Economics Institute of the Czech Academy of Sciences, Politickych veznu 7, P.O. Box 882, 11121 Prague 1, Czech Republic.

** We thank Robert Shiller, Marco Pagano, Thierry Foucault and seminar participants at ISEO 2015. Jan Novotný acknowledges funding from the European Community's Seventh Framework Program FP7PEOPLE-2011-IEF under grant agreement number PIEF-GA-2011-302098 (Price Jump Dynamics), the Centre for Econometric Analysis, and GAČR grant 14-27047S. Usual disclaimer applies. 


\section{Introduction}

The Value strategy represents one of the most commonly used investment strategies pursued in the investment world and in particular in the emerging markets, see Van der Hart et al. (2003) Cronqvist et al. (2015). For instance Warren Buffet one of the most well-known value investor chooses a low value and high-quality firms while making investments, see Gray and Carlisle (2012) for more information. The typical approach of a value investor is to assess the intrinsic value of the assets in the opportunity set based on some valuation metric. A quality metric will then be used to determine which assets are undervalued and are worth investing ${ }^{2}$.

The ratio between the share price and current earnings per share, the PE ratio, is widely considered to be an adequate gauge of under/overvaluation of a corporation's stock. Arguably, a more reliable indicator, the Cyclically-Adjusted Price Earning ratio or CAPE, can be obtained by replacing current earnings with a measure of PERMANEnT EARNINGS i.e. the profits that a corporation can earn, on average, over the medium to long run. In this study, we aim to understand the cross-sectional aspects of the dynamics of valuation metrics across global equity markets including both developed and emerging markets. Valuation measures involve various accounting ratios based on economic fundamentals, for instance, Piotroski score (Piotroski, 2000) is a representative example. An alternative is the $\mathrm{CAPE}$, or Shiller PE, an inflation-adjusted price-to-earning ratio defined as a price divided by a moving average of the earnings, evaluated in real terms, see Campbell and Shiller (1987). A compelling reason for using CAPE is that it goes deep into history, and tends to remove the business cycle effect of the economy and focuses more on the long run historical average of real earnings to better forecast present value of future dividends, as summarized by Molodovsky (1995). It further means that higher than average CAPE values means lower expected long-term returns.Therefore, an undervalued equity stock is one that has a CAPE value which is below its long-term historical value. Even though CAPE values are not intended to act as a leading indicator

\footnotetext{
${ }^{2}$ See, for instance, Asness et al. (2013) for discussion of the details of value and momentum strategies.
} 
to foresee discontinuity in asset prices shortly, however, higher CAPE values have often been associated with impending market corrections.

The advantage of the CAPE approach is that it can be employed to evaluate entire markets through the underlying traded benchmark index. Nowadays the value-based investment strategy is becoming increasingly popular for asset allocation, see, for instance, Meb Faber's new GVAL ETF. Employing such an approach, however, give rise to a new and challenging question, namely, when CAPE ratio can be used to make an investment decision for a portfolio of country-specific indices, how such a portfolio correlates across all the individual equity indices. In particular, the CAPE is a variable derived from price; however, it is fundamentally different to price. Thus, the correlation matrices based on the price of country-specific indices and the derived CAPE is in theory linked but not identical. The question becomes palpable in the case of emerging markets, which at present based on a benchmark market cap approach have an allocation of more than $12 \%$ in MSCI All-Country World Index (ACWI $)^{3}$. In light of the above discussion, in this work, we contribute to the existing literature in the following ways: We focus on the correlation matrix of CAPE for a list of 34 global economies including both developed and emerging economies and use the DCC GARCH model to capture the dynamics of the correlation. We then define the value spread in the correlation matrix as a difference between the DCC GARCH calculated correlation for the CAPE and the one obtained from the prices. We discuss the value spread to global economic events and assess it concerning value risk.

The concept of value risk is based on the premise that long-term investors while making investment decisions attempt to find undervalued assets in doing so, they solely consider the market price of the asset. The price itself; however, does not adequately capture the cross-sectional dynamics in value as the price in an efficient market world should reflect the long-term earning potential of the assets wrt. To all available information. However, this does not say anything about the valuation metric that investors are using to value

\footnotetext{
${ }^{3}$ MSCI via FactSet as of $31 / 12 / 2012$.
} 
assets and sharp decline is asset prices with the sudden onset of a heightened degree of risk aversion, which in most cases is preceded by a financial crisis. It is during these periods of euphoria and fear when asset prices can be detached from their intrinsic value and can be, under/overvalued until prices come back to equilibrium. Therefore, investors following a value-based strategy are exposed to a value risk wherein the valuation metric they are employing to forecast the long-term earning potential may not be adequate. The CAPE metric, for instance, considers that historical earnings and inflation, i.e. adjusting for business cycle effects, are a good forecast of future returns. In this chapter, we focus on this discrepancy and analyze this difference using empirical data. Thus, value investors may use our method as an advanced metric to evaluate the changes in the overall value of the entire portfolio and accurately estimate the corresponding risk.

To further expand the scope of this study, we have analyzed the evolution of the dynamic correlations across these markets, by computing correlations and covariance matrix in a Multivariate GARCH framework. One of the bigger challenges that these family of models has faced is an exponential increase in the number of parameters while computing the dynamics of the covariance of multiple assets. Bollerslev (1990) made the first attempt to address this problem by suggesting to keep the correlations constant over time and proposed the Constant Conditional Correlation, CCC GARCH model. Engle (2002) proposed Dynamic Conditional Correlation, DCC GARCH model which considered a time varying unconditional correlation matrix of the standardized residuals (See also Ding and Engle (2001), Bollerslev et al. (1992). These models allow one to see the change in correlations for a given pair of markets over time, and thereby enable us to better understand the dynamics of covariances arising in these markets. These dynamics can be attributed to a sudden change in expectations of market participants, and how shocks are transmitted across different markets, over time. As discussed above there have been multiple approaches to the DCC model, however for this study, we will be restricting ourselves to the Asymmetric Dynamic Conditional Correlation, A-DCC GARCH, of Cappiello et al. (2006). Our choice for A-DCC GARCH model rests on the assumption that 
asymmetric volatility arises because of the leverage effect and because of time-varying risk premium (volatility feedback) Black (1976), Christie (1982). However Bekaert and $\mathrm{Wu}(2000)$ have shown that leverage effect alone does not adequately explain the changes in volatility after a decrease in the asset price. Another stream of literature that has provided a plausible explanation of time-varying risk premium for asymmetries in return volatility is by focusing on the asymmetric response to joint bad news (negative returns for both assets) in correlations. This reasoning stems from the fact that a systematic negative shock induces downward pressure on the returns, in any given pair of assets and thereby will increase the variances of these securities. In a CAPM world if betas do not change, the covariances will increase, and if idiosyncratic variances do not proportionally change, correlations will also increase as well. In the end, correlations can, therefore, be higher after a negative innovation, than after a positive innovation of the same magnitude.

We use DCC GARCH models, to understand the dynamics of correlations in the given markets, as we are specifically interested in the value spread of the correlations obtained by taking a difference of the CAPE and return correlations. The value spread intuitively captures the effect of liquidity spillover from a given market to other markets in the same region, and how the markets have deviated from their historic cyclically adjusted earnings growth. These deviations can further shed light on the valuation risk for any given market as it helps in identifying ex-ante when a given market is undervalued/overvalued with reference to a particular asset pricing equilibrium model. On the other hand, the measure of value spreads is heavily skewed towards historical growth. Therefore, its predictions can be underpinned by a sudden revision in the future growth outlook especially in light of the recent central bank actions taken after the 2008 financial crisis. During this period, with the infusion of unprecedented amounts of liquidity in global financial markets, the historical growth rates have in a sense lost their relevance as most of the advanced economies are running below their projected long term trend growth and with significant output gap.

Our results show that, for the U.S. market, there is nearly no impact on the dynamics 
of the valuation metrics during the financial crisis thus affecting price and value in the same way. On the other hand, for the remaining two subsets, the financial crisis affected both price and the value of the respective markets differently and thus the investor, when valuing financial assets, should take this into consideration and adjust their valuation risk measure. Further, our results suggest that findings made for the U.S. market, or for the portfolio with the U.S. market as its component, cannot be generalized globally. Additionally, the value spreads also provides crucial information concerning market liquidity, and allows financial market regulators to foresee sudden changes in market liquidity and the spillover direction of hot money from other equity markets. Last but not the least, the European debt crisis does not reveal any significant impact on the value spreads. It thus suggests that the equity markets, that are considered for this study were not primarily affected by the national budget imbalances, and the crisis was wholly contained in other asset classes, namely in the sovereign bond market.

The remainder of the chapter is structured as follows: In Section 2, we describe our dataset. In Section 3, we specify the methodology we use to assess the dynamic correlation and to estimate the value spreads between price and CAPE. In Section 4, we provide results of the empirical exercise. In Section 5, we examine the results through the value investor. In Section 6, we briefly conclude.

\section{Data}

We use a panel of 34 countries, wherein for each country, we use the MSCI stock market index. The choice of the MSCI indices, as opposed to the local indices, is because MSCI indices are often tracked by ETFs, which can be directly traded. Therefore, our results have direct trading consequences. For each index, we record both the index level and the earnings per share for the index as it is available from Bloomberg. We accompany the data with the CPI time series from Morningstar to adjust prices in real terms. Our data covers the period from 2002 to 2014 using weekly frequency. The weekly data allows us to ignore the different time zones and address the issue of financial market synchronicity. At the 
same time, the weekly frequency is sufficient enough to capture the dynamics in the everchanging financial world. We use the following list of countries (in alphabetical order): Australia, Austria, Belgium, Brazil, Canada, Chile, China, Colombia, Finland, France, Germany, Hong Kong, India, Ireland, Israel, Italy, Japan, Malaysia, Mexico, Netherlands, Norway, Peru, Philippines, Poland, Portugal, Russia, South Africa, South Korea, Spain, Sweden, Switzerland, Taiwan, UK, and USA.

\subsection{Constructing the Cyclically Adjusted Price-to-Earnings ratio}

We employ Shiller's Cyclically Adjusted Price-to-Earnings ratio, CAPE, which is defined for a given stock market index $I$ at time $t$ as

$$
C A P E_{M ; t}^{I}=\frac{r P_{t}^{I}}{A v g_{M ; t}\left[r E P S_{t^{\prime}}^{I}\right]},
$$

where the numerator, $r P_{t}^{I}$, is the price level of the index $I$ at time $t$ expressed in real terms as

$$
r P_{t}^{I}=P_{t}^{I} \cdot \frac{C P I_{\mathcal{T}}^{I}}{C P I_{t}^{I}}
$$

where $C P I_{t}^{I}$ is the last published consumer price index at the domestic country to index $I$ at time $t, \mathcal{T}$ is the reference date taken as the last time in the sample and $P_{t}^{I}$ is the price level of the index, and the denominator $A v g_{M ; t}\left[r E P S_{t^{\prime}}^{I}\right]$, is the average of the earnings per share, expressed in real terms, over a past window $M{ }^{4}$

Let us remark, that we tacitly assume that $A v g_{M ; t}\left[r E P S_{t^{\prime}}^{I}\right]>0$, which is not always the case. As $A v g_{M ; t}\left[r E P S_{t^{\prime}}^{I}\right] \rightarrow 0+$, the $C A P E_{M ; t}^{I}$ is diverging, where for negative average earnings, the CAPE is negative as well. In fact, our choice of indices was driven by the fact that we consider only those indices, for which $A v g_{M ; t}\left[r E P S_{t^{\prime}}^{I}\right]>0$ and thus CAPE is well defined.

We further consider the weekly log-returns from the CAPE and the price level itself, both in real terms:

\footnotetext{
${ }^{4} E P S_{t}^{I}$ is published as 12 -month trailing average.
} 


$$
\begin{aligned}
p_{t}^{I} & =\log \left(r P_{t}^{I} / r P_{t-1}^{I}\right) \\
c_{M ; t}^{I} & =\log \left(C A P E_{M ; t}^{I} / C A P E_{M ; t-1}^{I}\right) .
\end{aligned}
$$

\subsection{Descriptive Statistics}

Tables 1 and 2 in the Appendix, provides the descriptive statistics for price-based and CAPE-based returns. Besides, we also document the mean, minimum and maximum of price and CAPE levels. First, the CAPE-based returns clearly show that CAPE ratio in itself is a dynamic variable with first four moments being comparable to those of returns, though, with lower kurtosis. Secondly, the value strategies are based on CAPE levels. The range of the CAPE levels suggests large variation over time, which is in line with the reasoning that CAPE itself is a non-stationary variable. Thus, we work with log-returns for both variables to ensure that we have a stationary time series. ${ }^{5}$

\section{Methodology}

To capture the time-varying correlation between the assets ${ }^{6}$, Cappiello et al. (2006) proposed a generalized autoregressive conditionally heteroskedastic process AGDCC-GARCH, which allows for the asymmetric generalized dynamic conditional correlation. Such an approach is an extension of the multivariate DCC-GARCH model by Engle (2002), and it allows for series-specific news impact and smoothing parameters and permits conditional asymmetries in correlation dynamics. ADCC-GARCH model is suitable to assess the correlation dynamics among the different asset classes, which is, in fact, the case when considering stock markets at the different development level. In this chapter, we employ the scalar version of the AGDCC GARCH model, which is numerically more feasible to be used for large-dimensional problems.

\footnotetext{
${ }^{5}$ CAPE-based strategies usually work with levels. Such an approach has to be carefully reviewed as it is based on the non-stationarity of the time series.

${ }^{6}$ We chose GARCH models as its a stylized fact that financial time series data exhibit Conditional Heteroskedasticity.
} 
Let us consider an $N$-dimensional vector of time series $\mathbf{x}_{\mathbf{t}}$, we then consider the dynamics of log-returns to be driven by the following equation

$$
\begin{aligned}
\mathbf{x}_{\mathbf{t}}= & \epsilon_{\mathbf{t}} \\
\epsilon_{t}= & \mathbf{H}_{t}^{1 / 2} \nu_{t} \\
\mathbf{H}_{t}= & \mathbf{D}_{t}^{1 / 2} \mathbf{R}_{t} \mathbf{D}_{t}^{1 / 2} \\
\mathbf{R}_{t}= & \operatorname{diag}\left(\mathbf{Q}_{t}\right)^{-1 / 2} \mathbf{Q}_{t} \operatorname{diag}\left(\mathbf{Q}_{t}\right)^{-1 / 2} \\
\mathbf{Q}_{t}= & \left(\overline{\mathbf{R}}-a^{2} \overline{\mathbf{R}}-b^{2} \overline{\mathbf{R}}-g^{2} \overline{\mathbf{N}}\right)+a^{2} \tilde{\epsilon}_{t-1} \tilde{\epsilon}_{t-1}^{\prime}+ \\
& +g^{2}\left(I\left[\tilde{\epsilon}_{t}<0\right] \circ \tilde{\epsilon}_{t}\right)\left(I\left[\tilde{\epsilon}_{t}<0\right] \circ \tilde{\epsilon}_{t}\right)^{\prime}+b^{2} \mathbf{Q}_{t-1} \\
\overline{\mathbf{R}}= & E\left[\tilde{\epsilon}_{t} \tilde{\epsilon}_{t}^{\prime}\right] \\
\overline{\mathbf{N}}= & E\left[\left(I\left[\tilde{\epsilon}_{t}<0\right] \circ \tilde{\epsilon}_{t}\right)\left(I\left[\tilde{\epsilon}_{t}<0\right] \circ \tilde{\epsilon}_{t}\right)^{\prime}\right] \\
\tilde{\epsilon}_{t}^{(i)}= & x_{t}^{(i)} / \sqrt{h_{t}^{(i)}},
\end{aligned}
$$

with $h_{t}^{(i)}$ being the standardized residuals from the univariate model.

As we see Eq. 1-8 shows the modeling of asset return and subsequently fitting an Asymmetric DCC-GARCH model. The matrix $\mathbf{H}_{t}$ provides a time varying variancecovariance matrix. In particular, the element $\left\{\mathbf{H}_{t}\right\}_{i j}$ captures the covariance between $i$-th and $j$-th component at time $t$.

\subsection{Value spreads}

Let us further denote the time-varying covariance matrix $\mathbf{H}_{t}$ estimated from the vector of the log-returns of price, $p_{t}=\left\{p_{t}^{I}\right\}_{I \in \text { Indices }}$, and the vector of the log-returns of CAPE, $c_{M, t}=\left\{c_{M, t}^{I}\right\}_{I \in \text { Indices }}$, as $\mathbf{H}_{t}^{p}$ and $\mathbf{H}_{t}^{c, M}$, respectively. The difference between the $p_{t}^{I}$ and $c_{M ; t}^{I}$ comes through the slowly varying process of $A v g_{M ; t}\left[r E P S_{t^{\prime}}^{I}\right]$. Such a process should not have a very significant contribution to the dynamics at the weekly frequency as it is an $M$-year average across a large number of underlying companies. Consequently, the matrices $\mathbf{H}_{t}^{p}$ and $\mathbf{H}_{t}^{c, M}$ should be similar to each other both in the diagonal and the off-diagonal terms 


$$
\mathbf{H}_{t}^{p} \cong \mathbf{H}_{t}^{c, M}
$$

The matrix $\mathbf{H}_{t}^{p}$ enters directly into the mean-variance optimization exercises, when an investor tries to optimize her portfolio. The matrix captures the covariance across markets and thus reflects the risk contagion, where the large off-diagonal elements suggest a strong channel for the value spread of the market shocks. On the other hand, $\mathbf{H}_{t}^{c, M}$ itself does not have a priori usage as the CAPE is used as a metric to value assets for the purpose of the Value investment. It is believed by practitioners that $C A P E_{M ; t}^{I}$ is properly normalized price, which allows one to set a threshold to determine the (low) value of the asset/index. The $C A P E_{M ; t^{-}}^{I}$ based valuation of markets is conventionally done on the univariate basis.

We, therefore, focus on the understanding the difference between $\mathbf{H}_{t}^{p}$ and $\mathbf{H}_{t}^{c, M}$ to assess whether the Value investment strategies reflect both univariate price variation as well as the covariance features across markets. In particular, if the off-diagonal terms differ the $C A P E_{M ; t}^{I}$-based valuation is not from the portfolio perspective anymore similar to normalized price and may lead to different cross-sectional properties.

For that purpose, we define the matrix of the covariance value spreads as

$$
\mathbf{S}_{t}=\mathbf{H}_{t}^{c, M}-\mathbf{H}_{t}^{p}
$$

where $\left\{\mathbf{S}_{t}\right\}_{i j}$ denotes the time-varying difference between the $C A P E_{M ; t^{-}}^{I}$ based and the price-based covariances between indices $i$ and $j$.

\section{Results}

We use the weekly data for 34 stock market indices and calculate the $C A P E_{7 ; t}^{I}$, the cyclically-adjusted price-to-earnings ratio based on the 7-year moving average of the inflation-adjusted earnings per share. ${ }^{7}$ For the weekly time series, we have estimated the matrices $\mathbf{H}_{t}^{p}$ and $\mathbf{H}_{t}^{c, M}$, respectively. ${ }^{8}$. To overcome the significant numerical burden

\footnotetext{
${ }^{7}$ We have considered the range of values between 5-10 years and all of them shows similar quantitative results.

${ }^{8}$ We have used Matlab Financial ToolBox.
} 
with the convergence of the full maximum likelihood model with 34 countries, we have split the sample into three regional sub-sets, the splitting has been based on the stock exchange opening times with respect to the GMT.

Subset No. 1: America. USA, Brazil, Canada, Chile, Colombia, Mexico, and Peru.

Subset No. 2: Europe. UK, Austria, Belgium, Finland, France, Germany, Ireland, Italy, Netherlands, Norway, Portugal, Poland, Spain, Sweden, and Switzerland.

Subset No. 3: Asia. Japan, Australia, China, Hong Kong, India, Israel, Malaysia, Philippines, Russia, South Africa, South Korea, and Taiwan.

The European subset in our sample is based on the strong economic and financial integration of the EU member states. It is due to this reason, why we left Russia for the Asia subset, as well as South Africa, which is highly linked through the commodity channel to China and Japan. Each of three subsets contains a large number of correlations. Further, in the Asia subset, there are 66 correlation pairs. To simplify the numerical estimations and make the system more tractable, we consider the biggest financial center for each region to act as a reference center. The first country in each of the subset, denoted by italics, is the benchmark for the given region, and all the correlations are computed concerning the given stock index.

\subsection{Benchmark}

To evaluate the time-varying correlation, we relate them to the benchmark based on the standard correlation. We use the standard Pearson correlation coefficient, $\rho$, for which we calculate the sample standard error $\sigma_{\rho}=\sqrt{\frac{1-\rho^{2}}{N-2}}$, where $N$ is the size of the sample. We estimate the static correlation for both the price-based and $C A P E_{7 ; t}$-based log-returns.

\subsection{Correlations}

We calculate both the static and dynamic correlations for each of the three regions separately, where we focus on the correlation between the respective financial center and 
other markets. Our primary objective is to understand the difference between the dynamics of the prices and the cyclically adjusted price-to-earnings ratio. Cyclically-adjusted earnings per share, $A v g_{M ; t}\left[r E P S_{t^{\prime}}^{I}\right]$, as defined in eq. 1, are not a smooth function even though we use a 7-year moving average. Figure 1 depicts the 7-year cyclically adjusted earnings per share, $A v g_{7 ; t}\left[r E P S_{t^{\prime}}^{I}\right]$, based on the 12-month trailing average, for three major financial centers. The figure confirms the intuition that earnings per share (EPS), even when using the 7 -year average are not smooth. Thus, the $C A P E_{7 ; t}$ is a normalized price with a denominator being a rapidly varying variable. The denominator, however, is not an independent variable with the numerator as the price of an asset is a function of the present value of future expected earnings.

We now focus our attention on the dynamics of the pair-wise correlations. Figures 2-4 depict the pair-wise correlations between the financial centers and the respective countries. The dash straight line depicts the static correlation between the price-based returns, where the shaded region enveloping the static correlation corresponds to $95 \%$ confidence interval; the solid straight line represents the static correlation between the $C A P E_{7 ; t^{-}}$ based log-returns; the time-varying dash line corresponds to the dynamic correlation of the price-based log-returns, and the solid time-varying line corresponds to the dynamic correlation between the $C A P E_{7 ; t^{-}}$based log-returns.

The variance in earnings thus brings a new dynamic component into the price process. The earnings itself relates to the economic performance of a given stock market, and, consequently, the country. Thus, both the price and the $C A P E_{7 ; t}$ are two related measures which track the economic performance of a country. As we do not want to consider a priori state, as to which one is more accurate, we rather proceed with a pairwise comparison of the two measures across the countries. The first hypothesis is thus to assess whether the static correlation between the two measures is statistically significant or not. Given we can calculate the confidence interval for the static correlation, we may answer the question accurately. By the second hypothesis, we aim to understand how the dynamic 
correlation is different with the static one and in particular when the static price-based correlation can act as a benchmark.

\subsubsection{America}

Figure 2 captures the pair-wise correlation for USA-Brazil, USA-Canada, USA-Chile, USA-Colombia, USA-Mexico, and USA-Peru. Firstly, except in the case of Colombia and Peru, the static correlations are not statistically distinguishable from each other as we can see from the confidence levels presented in the figure. Thus, even though we use the unsmoothed denominator, the overall impact on the correlation is not severe. Secondly, the dynamic correlations are following closely each other, except in 2002, where we see an opposite trend for the case of Brazil and Mexico, which presumably is due to the post dot-com bubble correction.

\subsubsection{Europe}

Figure 3 captures the pair-wise correlation for UK-Sweden, UK-Ireland, UK-Norway, UK-Portugal, UK-Poland, UK-Switzerland, UK-Finland, UK-Austria, UK-Belgium, UKSpain, UK-Italy, UK-Netherlands, UK-France, and UK-Germany. Compared to the case of America, there is a significant discrepancy in the static correlations between the two measures. It suggests that the two measures are capturing different economic effects and are not integrated in the same way. Secondly, the dynamic correlations further stress the difference between the two measures. Namely, the dynamic price-based correlation in most of the cases is close to the static one. Thus, the dynamic effects do not play such a significant role. However, the $C A P E_{7 ; t^{-}}$based dynamic correlation shows the shift in level - an effect linked to both the absolute difference between the static correlations - and the different patterns. For instance, during 2002 and 2003 the UK-Italy pair shows a different trend in the dynamic correlations. Such a pattern is present also in other countries. Thus, for European Union (EU) — which is a union of economically integrated countriesthere exist greater discrepancy in the valuation metric based on the two measures then countries in the American continent. 


\subsubsection{Asia}

Figure 4 captures the pair-wise correlation for Japan-Israel, Japan-South Africa, JapanRussia, Japan-India, Japan-China, Japan-Hong Kong, Japan-Malaysia, Japan-Philippines, Japan-Taiwan, Japan-Australia, and Japan-South Korea. Firstly, the difference between the two static correlations is statistically significant for all country pairs. It suggests that the two valuations are capturing different economic factors. Secondly, the dynamic correlations show a different pattern. For pairs like Japan-Malaysia and Japan-Philippines, the dynamic correlations are tightly connected and evolve in a similar manner, presumably because of a higher integration in the set of economic factors both exogenous as well as endogenous influencing these markets. On the other hand, for pairs like Japan-China and Japan-Russia, there is a disentanglement between the dynamic of the two measures. This further shows that even though the set of exogenous factors affecting these markets remain similar, the set of idiosyncratic endogenous variables have a big impact on these markets.

In conclusion, the two measures tend to capture the value of financial markets, and, in particular, the dynamics of the economic integration in a significantly different ways. Such a difference is more pronounced outside the American continent, or, rather for all the pairs except those with the USA. Our use of dynamic correlations further amplifies this difference. Consequently, the stylized fact about the link between the price- or the value of a market - and the financial distress is not necessarily preserved when using other valuation metrics, even for those which are popular for the value investment. In the following section, we focus more closely on the value spreads between the dynamic correlations, $\mathbf{S}_{t}$, as defined in equation (11).

\subsection{Value spreads}

We calculate the value spreads between the dynamic correlations for measures as defined in equation (11). To assess the econometric significance of the value spread, we set the confidence bounds based on the static correlations. Namely, for a given pair of countries, we estimate the static correlations using price-based and $C A P E_{7 ; t^{-}}$based log-

returns. For both the correlations, we calculate the error $\sigma_{\rho}=\sqrt{\frac{1-\rho^{2}}{N-2}}$. Then, we set 
the confidence bounds for the value spreads as $\sigma_{S}=\sqrt{\sigma_{P}^{2}+\sigma_{C A P E}^{2}}$. Thereby, we can benchmark the value spreads against the static case and assess the significance of the difference between the dynamics of the two valuation measures.

In Figures 5-7, we depict the dynamics of the value spread $S_{t}^{(i, j)}$ between the two countries, the dotted line, together with the static value spreads, the dashed line, as well as the shaded region corresponding to the 95\% Confidence interval based on the static value spreads. Therefore, every time the dynamic value spread lies outside the shaded area, we will consider that the pair-wise dynamics of the two valuation metrics is statistically different from each other.

\subsubsection{America}

Figure 5 captures the pair-wise value spreads for USA-Brazil, USA-Canada, USAChile, USA-Colombia, USA-Mexico, and USA-Peru. Overall, the value spreads between dynamic correlations are rather indistinguishable from each other as most of the time, the value spreads do not leave the shaded region. The value spreads tend to be negative meaning that the $C A P E_{7 ; t}$-based returns are less correlated than prices. The figure shows that in the post dot-com bubble period, the value spreads tend to leave confidence interval, and is often in the negative territory. Thereby suggesting that market prices were not in equilibrium as proposed by the CAPE measure capturing the historical long term growth, this deviation can be inferred as a sign of panic or exuberance in the market. For instance post dot-com bubble the earnings estimate of Brazil, Colombia, Mexico, and Peru got detached from their historical earnings with the only exception of Canada and Chile. It further suggests that there was liquidity spillover from the USA equity markets, as all the correlations are referenced to USA, and, therefore, suggests the influx of hot money into the financial markets of these economies. This deviation of prices from their long-term earnings can explain that market participants were driven by euphoria, and asset prices deviated from their equilibrium prices. Further, post 2008 crisis we can see that prices again got disentangled from their historical earnings, in Colombia, Peru, Chile and for a short interval from Brazil and Canada. However, in this case, money was flowing out of these economies, market participants were driven by a state of panic and were severely 
penalizing these markets, by rapidly discounting the earnings far greater than suggested by the historical trend.

\subsubsection{Europe}

Figure 6 captures the pair-wise value spreads for UK-Sweden, UK-Ireland, UK-Norway, UK-Portugal, UK-Poland, UK-Switzerland, UK-Finland, UK-Austria, UK-Belgium, UKSpain, UK-Italy, UK-Netherlands, UK-France, and UK-Germany. Compared to the case of America, the value spreads tend to be larger in absolute value, suggesting much greater valuation discrepancy among countries. This is, in fact, surprising, as one would expect that Europe is composed of the countries, which are highly economically and financially integrated, more than the countries across the North and South America. Further, in most of the European pairs, we see a spike around the default of Lehman Brothers, suggesting that the impact of the financial crisis was transmitted through the relative the value of financial assets in European capital markets. On the other hand, the European debt crisis, which started in Europe does not seem to have such a severe effect on the dynamics of market valuations vis-a-vis with the financial crisis post-Lehman bankruptcy.

\subsubsection{Asia}

Figure 7 captures the pair-wise value spreads for Japan-Israel, Japan-South Africa, Japan-Russia, Japan-India, Japan-China, Japan-Hong Kong, Japan-Malaysia, JapanPhilippines, Japan-Taiwan, Japan-Australia, and Japan-South Korea. The value spreads across Asia resemble more closely to Europe, than when compared to America. We see a significant discrepancy between Japan and Russia and Japan and Hong Kong. Otherwise, the valuation metrics between the countries across the last subset of countries is rather similar. For the first pair of countries, the discrepancy is not so surprising as Japan and Russia are not tightly linked - strictly in an economic, financial or political sense. Similar to Europe, we see an impact of the financial crisis on the dynamics of valuations as the value spreads tend to move away from the static bounds. 


\section{Value Portfolio: The Risk Angle}

We now summarize the results from an investor's standpoint using a value-based investment strategy with the opportunity set being individual stock markets across the globe. Such investments with minimal transaction costs can be carried out through Exchange Traded Funds (ETF's), which track the performance of an underlying tradable broad market index. Among those Indices, the MSCI family is in particular very common and is therefore used in this chapter.

Such a strategy works as follows: Investor operates with the opportunity set consisting of stock market indices, or the corresponding ETFs, where for each of the indices the investor continuously assesses the valuation metric. Thus, at every point in time, the investor can rank the markets based on its value. Also, the valuation metrics can be used to assess the cardinal value of the markets. Based on the results of the valuation metric, the investor can form a respective trading strategy ${ }^{9}$. Thus, the investor uses the valuation metric to screen the investment universe and to make investment decisions. While making an investment decision on the optimal mix of assets in the portfolio, the investor puts the valuation metric aside and focuses on the under/over valuation of the assets for a given risk-return metric. In this stage, the relative performance of a valuation metric across assets plays a central role.

Our results clearly demonstrate that using a static correlation, which is the most intuitive choice, does not provide real-time information concerning the co-movements between markets during the crisis period. For instance, during the post-dot-com bubble period, we can observe that the correlation between the markets across the American continent were very volatile. Therefore, an investor relying solely on static correlation for asset allocation cannot take into account the misvaluation period during the formation of an asset bubble. In fact, the need for dynamic correlation can be illustrated in all three

\footnotetext{
${ }^{9}$ Particular choices are long-short portfolio based on buying long highly undervalued and going short on overvalued assets, thereby allowing prices to fall in equilibrium. Alternatively a long only strategy on the most undervalued assets anticipating that prices will rise in future to their intrinsic value.
} 
subsets during the recent financial crisis. Further, our empirical results for the value spreads suggest that the pair-wise dynamics of the valuation metric vary significantly across countries. For the subset of countries from American continents, the valuation metric closely resembles the price process, even for seemingly unrelated countries like U.S. and Brazil. On the other hand, the economically and financially integrated countries in Europe show significantly different pair-wise dynamics from the price process, as we can see from the value spreads. The difference among European countries is far more significant than for the countries from the Asian subset.

\section{Conclusions}

In this work, we have introduced the notion of value spread as a measure of crosssectional dynamics between price and the CAPE ratio, which serves as an alternative measure for asset pricing. The value spread helps investors to identify periods of asset mispricing and highlights the cross-sectional differences in valuation dynamics for all the major financial centers especially during the financial crisis. We have divided the given set of countries in our sample into three subsets: America, Europe, and Asia. For each region, we have calculated pair-wise dynamics between the financial center of that region and other countries. The subset of the U.S. market shows nearly no impact on the dynamics of the valuation metrics thus affecting price and value in the same way. On the other hand, for the remaining two subsets, the financial crisis affected both price and the value of the respective markets differently. This valuation metric shows different properties for different countries and thus the investor when valuing a financial asset should take this into consideration and adjust their valuation risk measure. Such an observation has direct consequence for valuation of financial assets in emerging economies as the capital markets in these economies are still evolving, compared to capital markets in advanced economies.

In particular, our results suggest that the findings made for the U.S. market, or for the portfolio with the U.S. market as its component, cannot be generalized globally. Our results demonstrate that the recent financial crisis was not related to asset mispricing, as 
opposed to the dot-com era, which we capture at the beginning of our sample. During the dot-com period, asset prices were detached from their intrinsic value as the markets were driven by irrational euphoria, however during the post-bubble period, one can observe that the value dynamics were converging towards the price dynamics. Additionally, the value spreads also provides crucial information concerning market liquidity, and allows financial market regulators to foresee sudden changes in market liquidity and the spillover direction of hot money from other equity markets. Finally, the European debt crisis does not reveal any significant impact on the value spreads. It thus suggests that the equity markets, that are considered for this study were not primarily affected by the national budget imbalances, and the crisis was wholly contained in other asset classes, namely in the sovereign bond market. Therefore, we may consider that the severity of such a crisis spilling over to global equity markets was considerably small. 
Figure 1: 7-year cyclically adjusted earnings per share

(a) USA

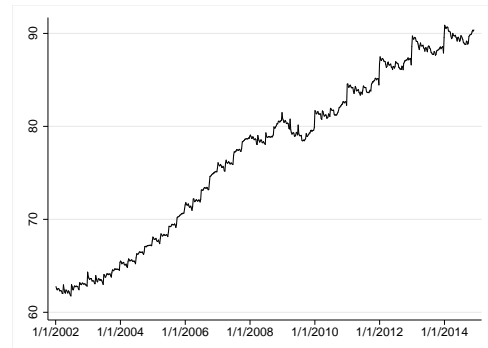

(b) United Kingdom

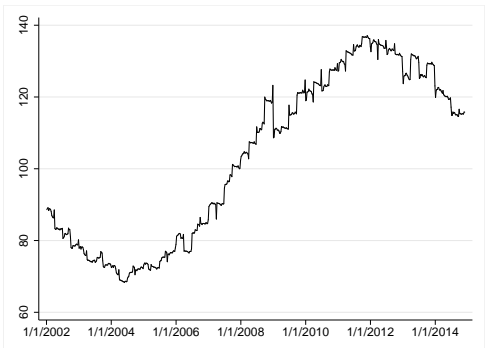

(c) Japan

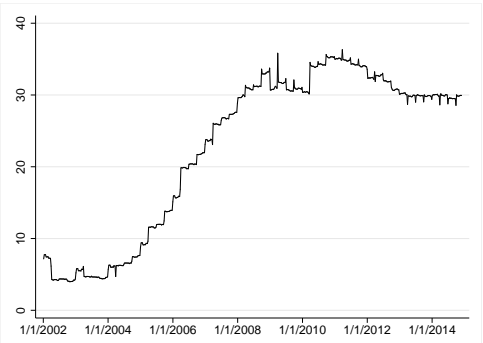

Note: Figure depicts the 7-year cyclically adjusted earnings per share, $A v g_{7 ; t}\left[r E P S_{t^{\prime}}^{I}\right]$, based on the 12-month trailing average.

Figure 2: Correlations: America

(a) USA-Brazil

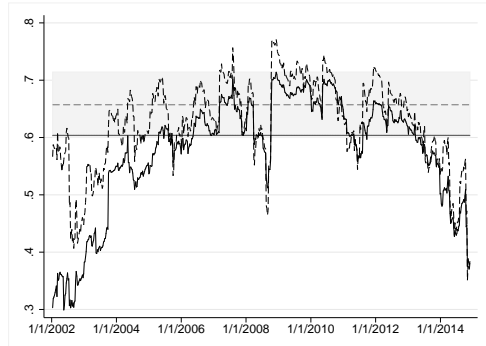

(d) USA-Colombia

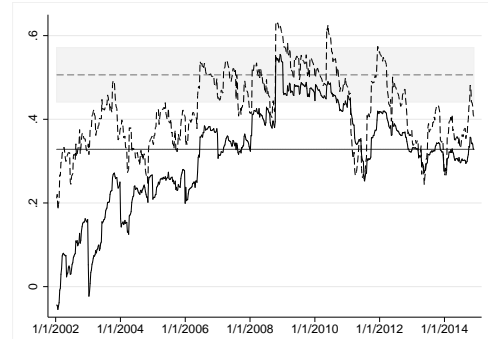

(b) USA-Canada

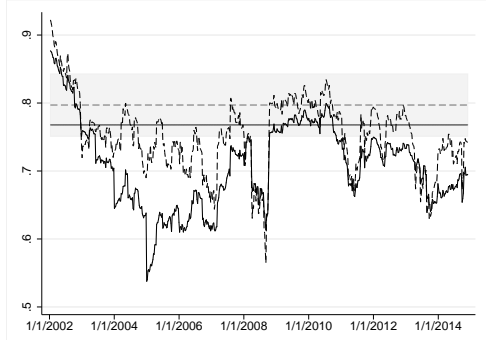

(e) USA-Mexico

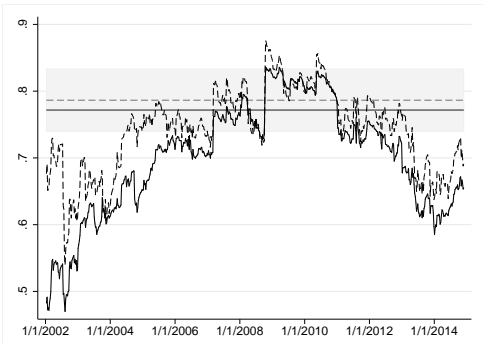

(c) USA-Chile

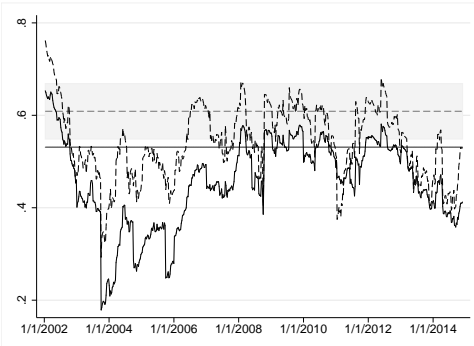

(f) USA-Peru

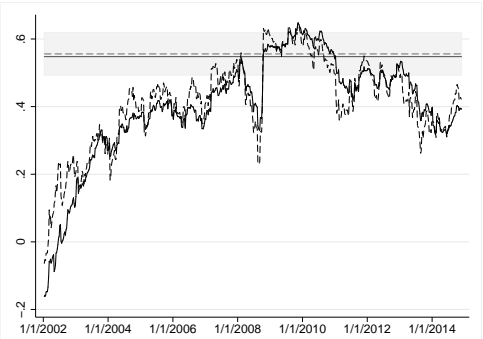

Note: The solid black and gray lines depict the dynamic and the static correlations between the $C A P E_{7 ; t}^{I}, \mathbf{H}_{t}^{c, 7}$, respectively; the dash black and gray lines illustrates the dynamic and the static correlation between the price levels, $\mathbf{H}_{t}^{p}$, respectively. The shaded region shows the $95 \%$ confidence interval for the static correlation of the price levels, which serves as a benchmark. 
Figure 3: Correlations: Europe

(a) UK-Sweden

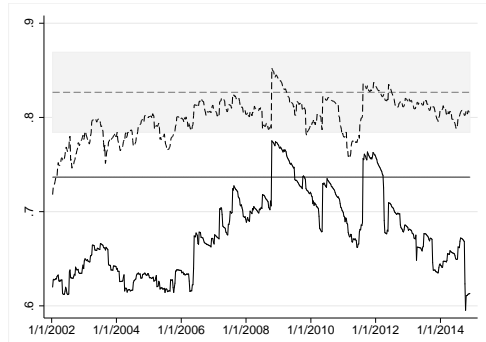

(d) UK-Portugal

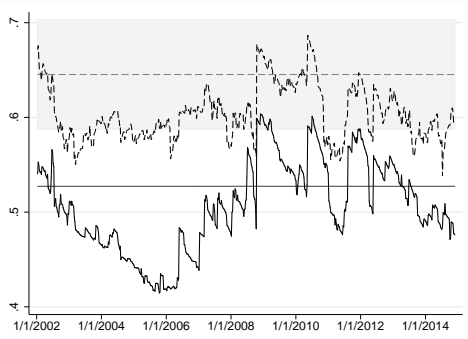

(g) UK-Finland

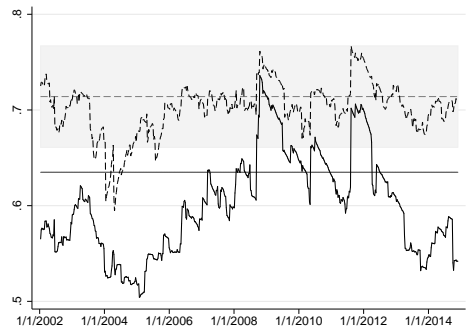

(j) UK-Spain

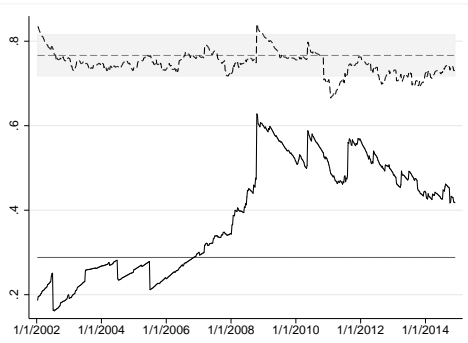

(m) UK-France

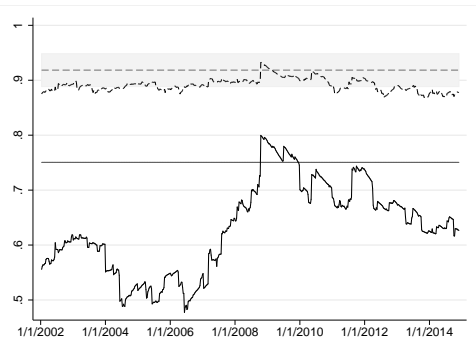

(b) UK-Ireland

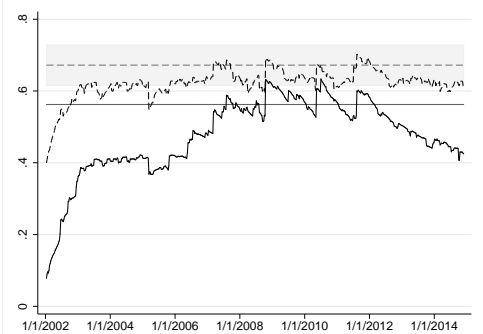

(e) UK-Poland

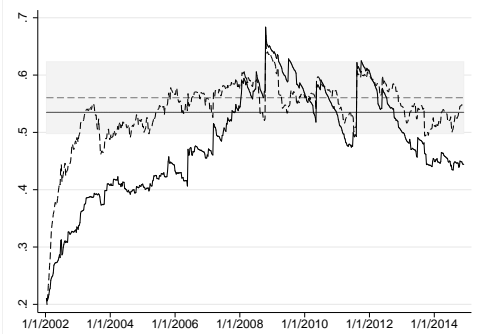

(h) UK-Austria

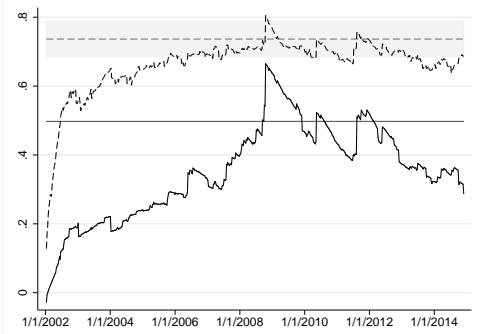

(k) UK-Italy

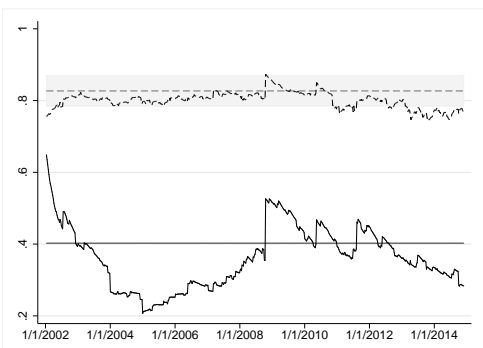

(n) UK-Germany

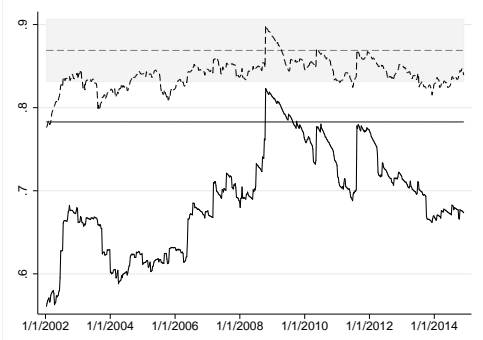

(c) UK-Norway

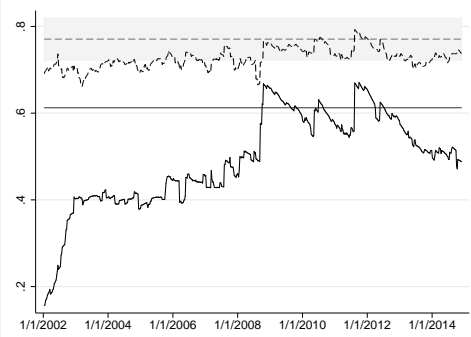

(f) UK-Switzerland

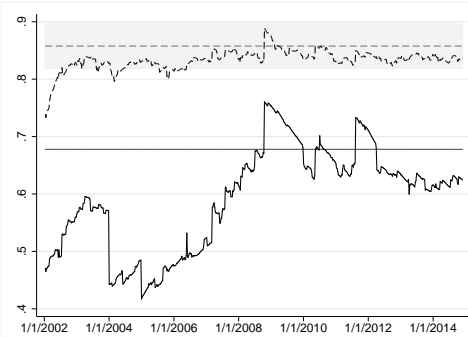

(i) UK-Belgium

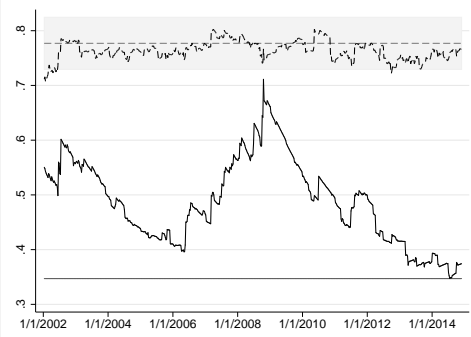

(l) UK-Netherlands

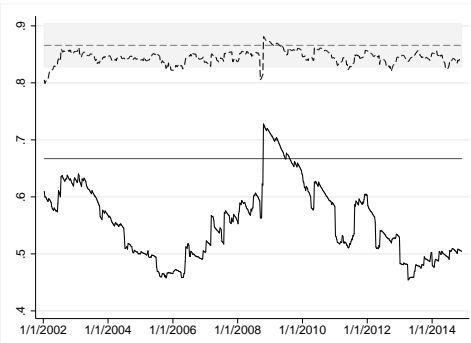

Note: The solid black and gray lines depict the dynamic and the static correlations between the $C A P E_{7 ; t}^{I}, \mathbf{H}_{t}^{c, 7}$, respectively; the dashed black and gray lines illustrates the dynamic and the static correlation between the price levels, $\mathbf{H}_{t}^{p}$, respectively. The shaded region shows the $95 \%$ confidence interval for the static correlation of the price levels, which serves as a benchmark. 
Figure 4: Correlations: Asia

(a) Japan-Israel

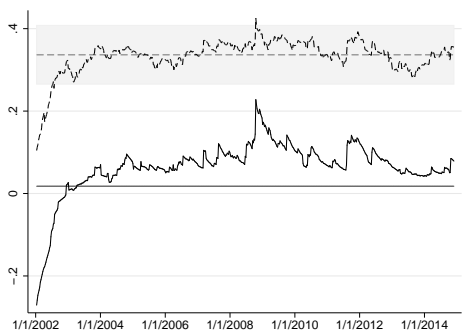

(d) Japan-India

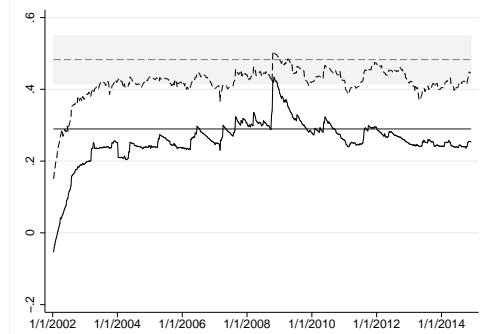

(g) Japan-Malaysia

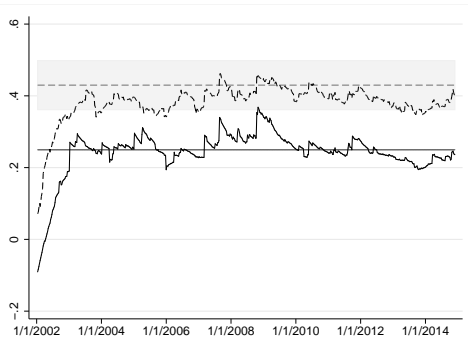

(j) Japan-Australia

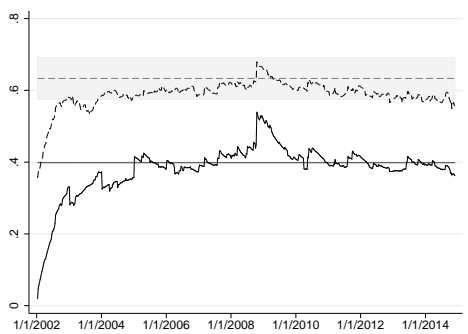

(b) Japan-South Africa

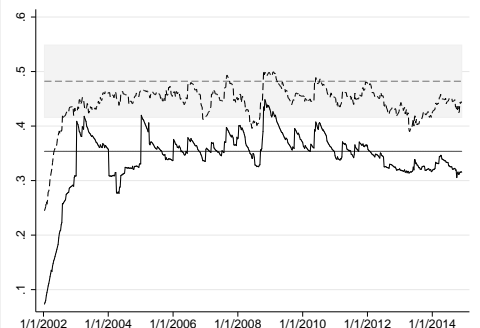

(e) Japan-China

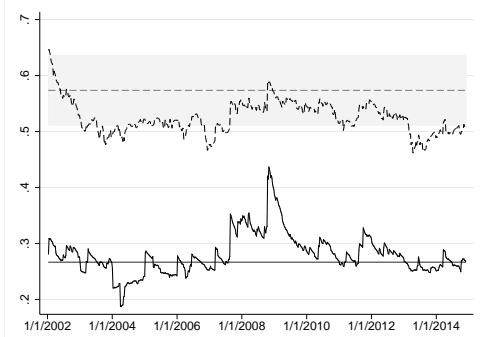

(h) Japan-Philippines

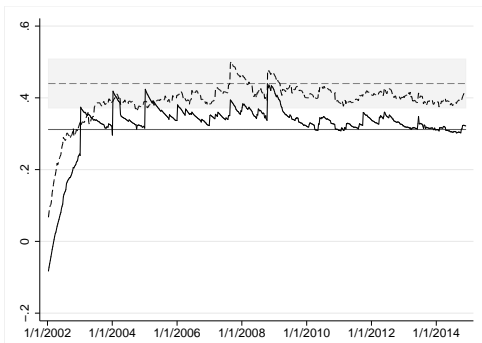

(k) Japan-South Korea

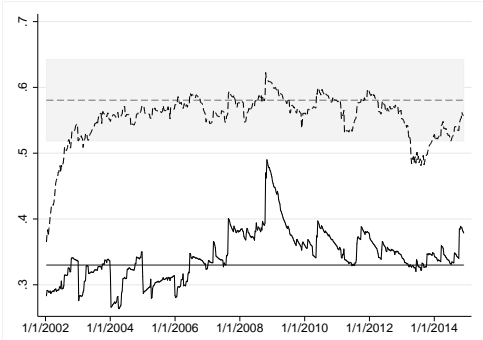

(c) Japan-Russia

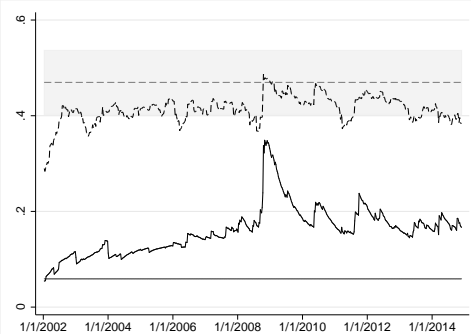

(f) Japan-Hong Kong

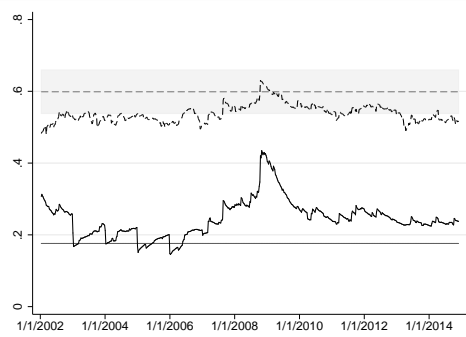

(i) Japan-Taiwan

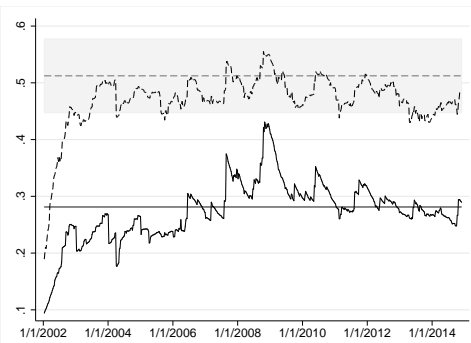

Note: The solid black and gray lines depict the dynamic and the static correlations between the $C A P E_{7 ; t}^{I}, \mathbf{H}_{t}^{c, 7}$, respectively; the dash black and gray lines illustrates the dynamic and the static correlation between the price levels, $\mathbf{H}_{t}^{p}$, respectively. The shaded region shows the $95 \%$ confidence interval for the static correlation of the price levels, which serves as a benchmark. 
Figure 5: Value spreads: America

(a) USA-Brazil

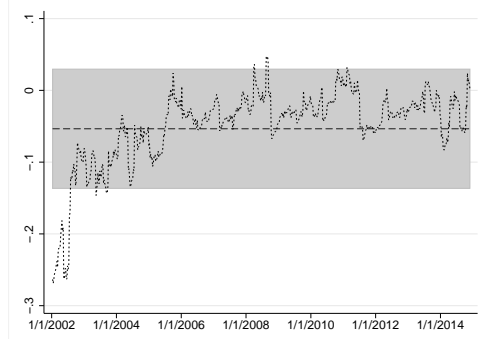

(d) USA-Colombia

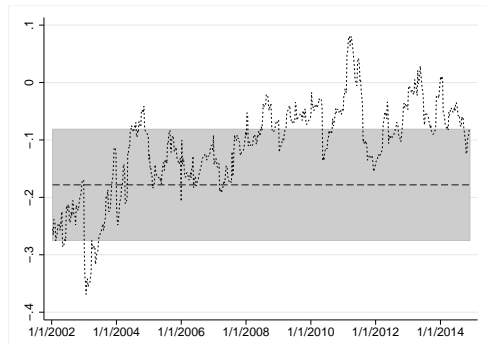

(b) USA-Canada

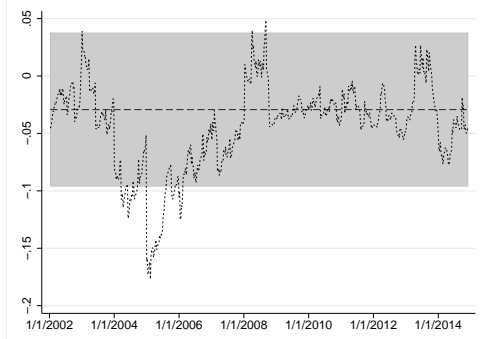

(e) USA-Mexico

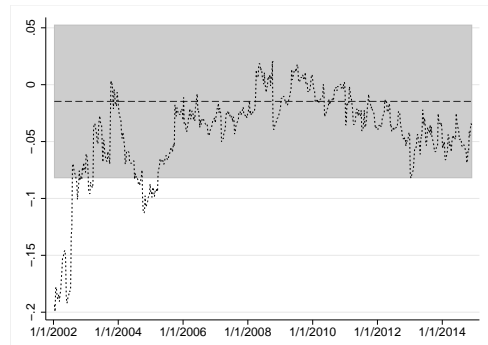

(c) USA-Chile

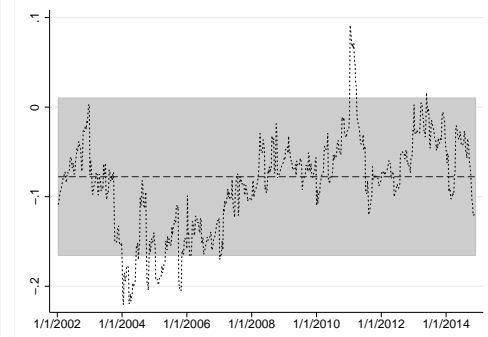

(f) USA-Peru

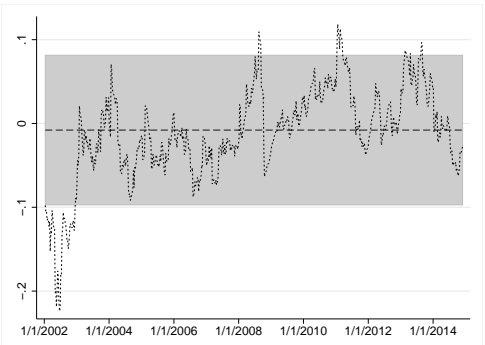

Note: The dashed line depicts the value spread between the static correlations of the price-based and $C A P E_{7 ; t}^{I}$-based valuation measures, the shaded region corresponds to the $95 \%$ confidence interval of the static value spreads, and the dotted line corresponds to the dynamic value spreads $S_{t}$. 
Figure 6: Value spreads: Europe

(a) UK-Sweden

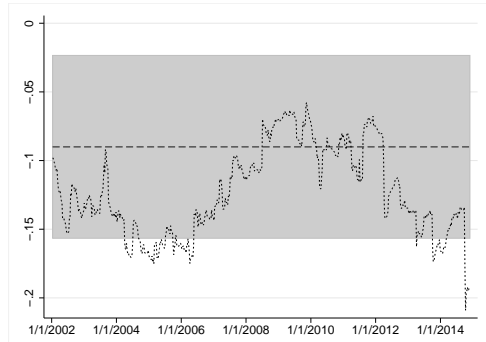

(d) UK-Portugal

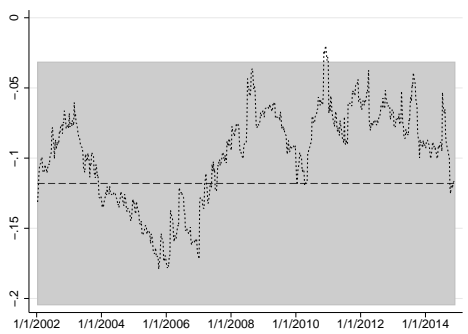

(g) UK-Finland

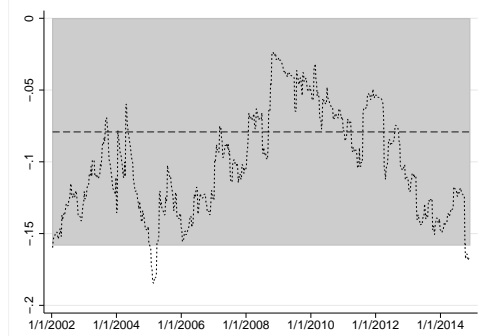

(j) UK-Spain

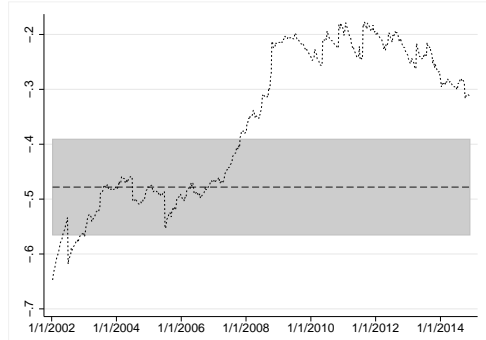

(m) UK-France

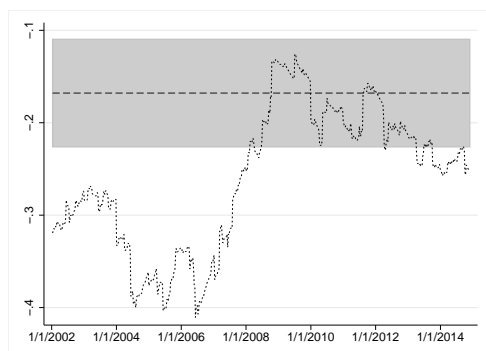

(b) UK-Ireland

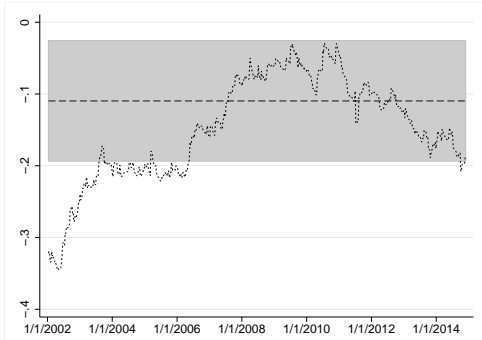

(e) UK-Poland

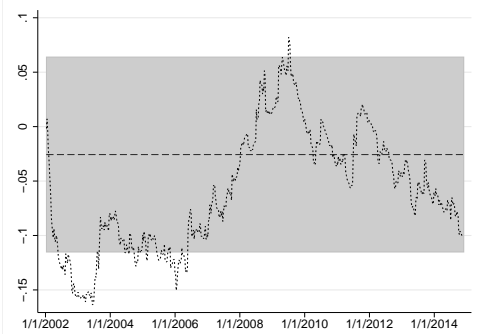

(h) UK-Austria

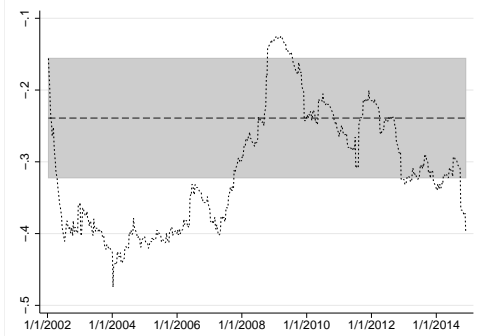

(k) UK-Italy

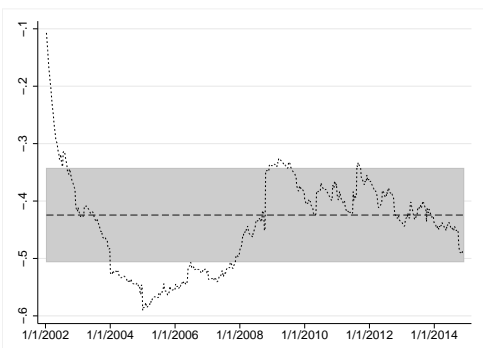

(n) UK-Germany

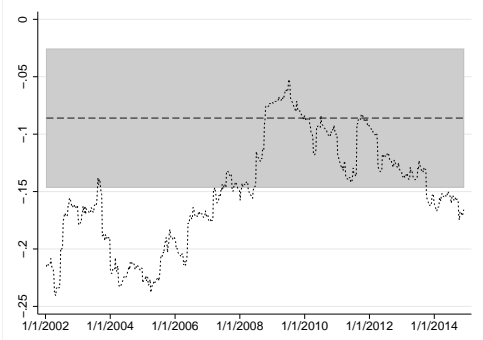

(c) UK-Norway

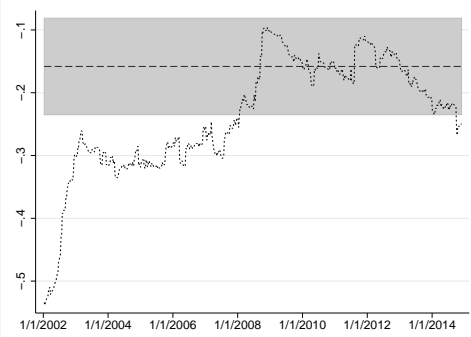

(f) UK-Switzerland

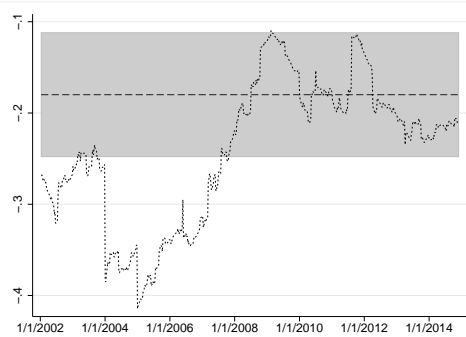

(i) UK-Belgium

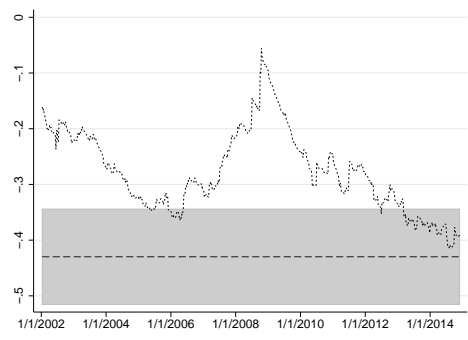

(l) UK-Netherlands

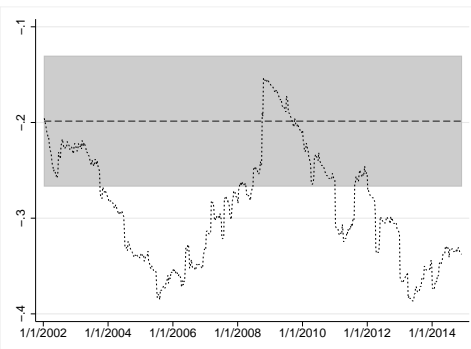

Note: The dashed line depicts the value spread between the static correlations of the price-based and $C A P E_{7: t}^{I}$-based valuation measures, the shaded region, corresponds to the $95 \%$ confidence interval of the static value spreads, and the dotted line corresponds to the dynamic value spreads $S_{t}$. 
Figure 7: Value spreads: Asia

(a) Japan-Israel

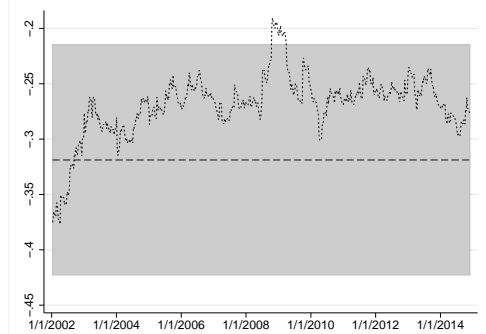

(d) Japan-India

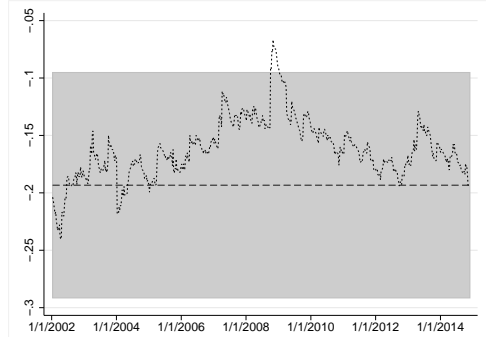

(g) Japan-Malaysia

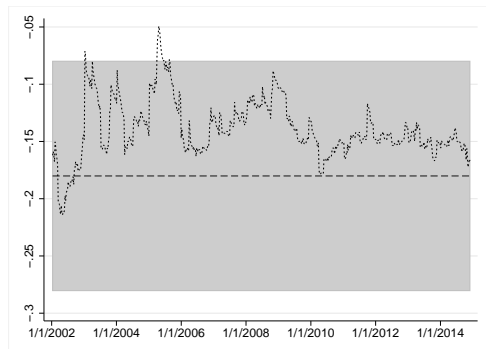

(j) Japan-Australia

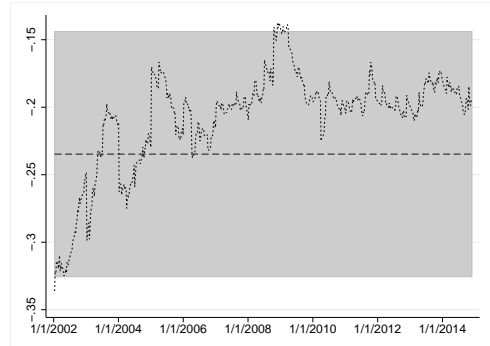

(b) Japan-South Africa

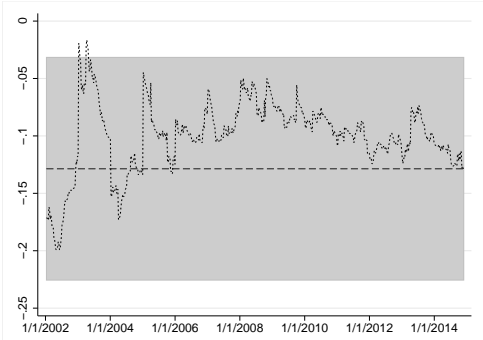

(e) Japan-China

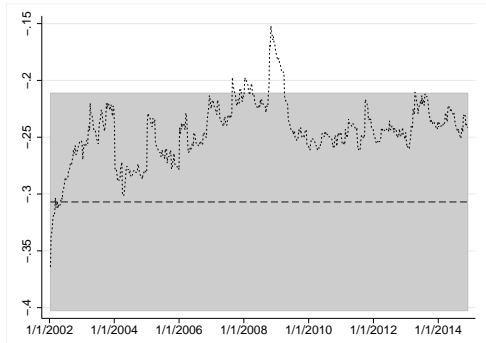

(h) Japan-Philippines

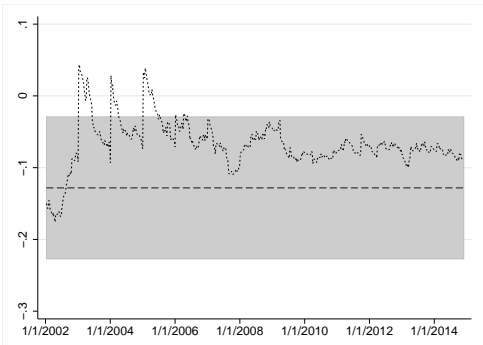

(k) Japan-South Korea

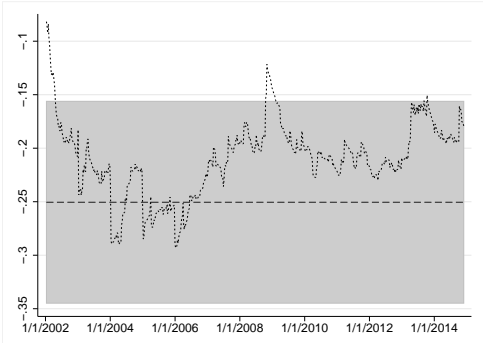

(c) Japan-Russia

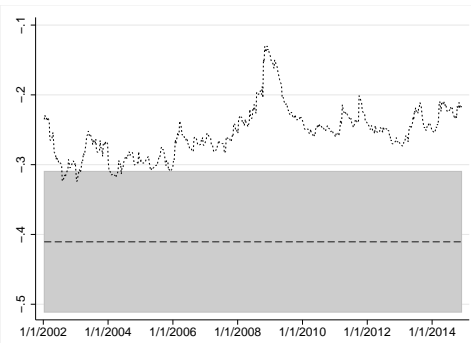

(f) Japan-Hong Kong

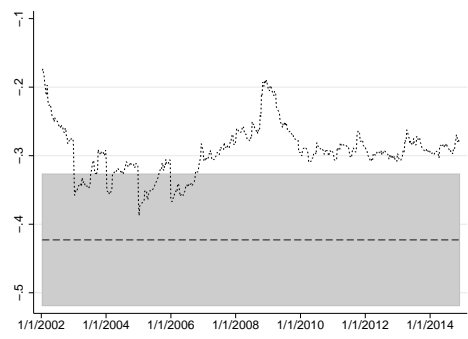

(i) Japan-Taiwan

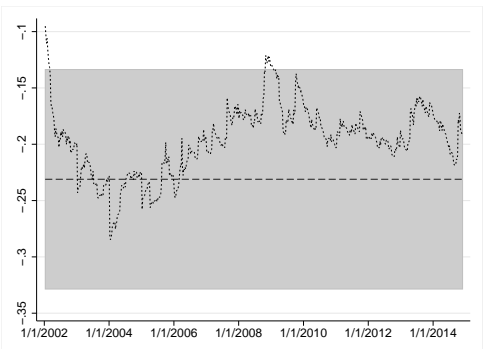

Note: The dashed line depicts the value spread between the static correlations of the price-based and $C A P E_{7: t}^{I}$-based valuation measures, the shaded region corresponds to the $95 \%$ confidence interval of the static value spreads, and the dotted line corresponds to the dynamic value spreads $S_{t}$. 


\section{Appendix}

Table 1 presents the descriptive statistics for log-returns for each stock market index observed at the weekly frequency. Also, we provide necessary information about the price levels. Table 2 documents the descriptive statistics for log-returns based on CAPE for each stock market index observed at a weekly frequency. Further, we provide the mean, min and max for CAPE as many value strategies are based directly on the level of the CAPE itself despite being obviously a non-stationary time series.

If we focus on the levels of both price and CAPE, we see that the range of prices and the range of CAPE values are not in all cases in line. For instance, levels of CAPE for Belgium varies between 4.447 and 1153.587, i.e., by nearly a three orders of magnitude while prices of the index are in the range between 28.690 and 120.720. This further stresses the fact that prices and CAPEs may have different dynamics and CAPE, being a price normalized by permanent income, may vary significantly. A similar disparity between prices and CAPE can be observed in Russia also. 
Table 1: Descriptive Statistics: MSCI Market Indices

\begin{tabular}{|c|c|c|c|c|c|c|c|c|c|}
\hline & \multicolumn{3}{|c|}{ Panel A: Price levels } & \multicolumn{6}{|c|}{ Panel B: Price log-returns } \\
\hline & Mean & Min & $\operatorname{Max}$ & Mean & Std. & Skewness & Kurtosis & Min & Max \\
\hline Australia & 909.034 & 548.270 & 1363.610 & 0.0007 & 0.1591 & -0.9797 & 9.3399 & -0.1649 & 0.0973 \\
\hline Austria & 158.642 & 73.580 & 348.870 & 0.0000 & 0.2711 & -1.9573 & 18.8110 & -0.3605 & 0.1742 \\
\hline Belgium & 68.952 & 28.690 & 120.720 & 0.0001 & 0.2224 & -1.5534 & 11.8074 & -0.2175 & 0.1020 \\
\hline Brazil & 2156.354 & 285.720 & 4664.740 & 0.0018 & 0.3791 & -0.6810 & 8.1804 & -0.3306 & 0.2562 \\
\hline Canada & 114.901 & 731.910 & 1981.460 & 0.0010 & 0.1719 & -0.9358 & 9164 & -0.1697 & 0.1413 \\
\hline Chile & 1577.873 & 389.060 & 2921.800 & 0.0016 & 0.2475 & -1.7553 & 20.6 & -0.3466 & 0.1913 \\
\hline China & 46.489 & 13.160 & 100.820 & .0019 & 0.2741 & -0.3179 & & -0.2229 & 0.1776 \\
\hline Colombia & 644.737 & 53.270 & 1393.460 & 0.0042 & 0.2709 & -1.2531 & 11.2543 & -0.2902 & 0.1278 \\
\hline Finland & 104.827 & 58.470 & & -0.0007 & 0.2813 & -0.4659 & & -0.1672 & 0.1234 \\
\hline & 108.407 & 67.910 & 162.940 & -0.0001 & 0.2157 & -1.1115 & & -0.2450 & 0.1228 \\
\hline Germany & 95.915 & 46.520 & 140.700 & 0.0003 & 0.2336 & -0.7784 & 982 & -0.2385 & 0.1564 \\
\hline Hong Kong & 8714.399 & 3946.570 & 13494.679 & & 0.2042 & & & -0.1730 & 0.0981 \\
\hline & 25.425 & 124.660 & 1045.250 & 0.0029 & 0.2319 & & & -0.1900 & 0.1366 \\
\hline Ireland & 56.186 & 18.710 & 126.180 & -0.0013 & 0.2854 & -1.7 & & -0.3767 & 0.1705 \\
\hline & 197.773 & 84.570 & & & 0.2001 & & & -0.1247 & 0.0900 \\
\hline & 5.382 & 38.530 & 128.6 & 007 & 0.2333 & & & -0.2512 & 0.1025 \\
\hline & & & & & & & & & 0.0964 \\
\hline & 442.750 & 234.310 & & & 0.1345 & & & -0.1024 & 0.0764 \\
\hline & 4602.442 & 1307.990 & 7683.990 & 0.0020 & 0.2805 & & & -0.3068 & 0.2255 \\
\hline & & & & & & & & -0.2968 & 0.0939 \\
\hline & 2108.751 & 785.370 & 3474.929 & 0.0011 & 0.2403 & -1.2146 & & -0.2461 & 0.1534 \\
\hline & 884.150 & 143.810 & 1887.540 & 0.0032 & 0.3021 & -0.6556 & & -0.2936 & 0.2206 \\
\hline Phili & 606.535 & 203.620 & 1245.319 & 0.0021 & 0.2227 & -0.5674 & & -0.1960 & 0.1252 \\
\hline & 1597.544 & 751.750 & 2690.310 & 0.0008 & 0.2301 & -0.3784 & & -0.1670 & 0.1608 \\
\hline Por & 69.680 & 38.890 & & -0.0011 & 0.1989 & -1.0 & & -0.1898 & 0.0778 \\
\hline & 49.904 & 237.470 & 1618.319 & 0.0012 & 0.3775 & -0.1366 & 5633 & -0.2806 & 0.4275 \\
\hline & 650.738 & 216.240 & 1309.080 & 0.0020 & 0.1897 & & & -0.0970 & 0.1626 \\
\hline South Korea & & 159.530 & & & & & & -0.2140 & 0.1882 \\
\hline & 110.286 & 62.570 & 179.370 & 0.0002 & 0.2407 & -0.9328 & & -0.2411 & 0.1200 \\
\hline & 7234.157 & 3128.550 & 10805.889 & 0.0008 & 0.2268 & -0.8630 & 8.5443 & -0.2267 & 0.1260 \\
\hline Switzerland & 873.908 & 504.010 & 1248.870 & 0.0005 & 0.1858 & -1.5044 & 18.8001 & -0.2479 & 0.1230 \\
\hline Taiwan & 272.479 & 155.860 & 376.690 & 0.0004 & 0.2163 & -0.2923 & 5.5171 & -0.1148 & 0.1722 \\
\hline United Kingdom & 1617.446 & 1042.840 & 2025.689 & 0.0003 & 0.1793 & -1.3372 & 17.2138 & -0.2343 & 0.1255 \\
\hline USA & 1273.067 & 683.380 & 2052.750 & 0.0008 & 0.1785 & -0.8597 & 11.3135 & -0.2008 & 0.1136 \\
\hline
\end{tabular}

Note: This table reports the descriptive statistics for prices for each of the 34 stock market indices. Panel A captures the properties of the price levels while Panel B captures logreturns based on prices for 34 countries observed at a weekly frequency. Std. stands for the standard deviation expressed in annualized terms. 
Table 2: Descriptive statistics: CAPEs

\begin{tabular}{|c|c|c|c|c|c|c|c|c|c|}
\hline & \multicolumn{3}{|c|}{ Panel A: CAPE levels } & \multicolumn{6}{|c|}{ Panel B: CAPE log-returns } \\
\hline & Mean & Min & Max & Mean & Std. & Skewness & Kurtosis & Min & $\operatorname{Max}$ \\
\hline Australia & 18.361 & 10.653 & 25.313 & -0.0005 & 0.1759 & -0.8520 & 7.1649 & -0.1649 & 0.0947 \\
\hline Austria & 18.119 & 4.695 & 39.085 & -0.0009 & 0.3671 & -0.9724 & 13.4189 & -0.3606 & 0.3105 \\
\hline Belgium & 41.585 & 4.447 & 1153.587 & 0.0035 & 0.8711 & 8.1573 & 139.3207 & -0.8079 & 2.0418 \\
\hline Brazil & 13.416 & 3.349 & 33.311 & 0.0001 & 0.4296 & -1.0034 & 10.8721 & -0.4114 & 0.2789 \\
\hline Canada & 20.199 & 12.342 & 27.521 & -0.0004 & 0.1828 & -1.0293 & 10.5705 & -0.1702 & 0.1365 \\
\hline hile & 25.161 & 9.508 & 43.769 & 0.0001 & 0.2764 & -1.2375 & 14.2081 & -0.3449 & 0.1849 \\
\hline China & 17.425 & 5.194 & 49.047 & 0.0009 & 0.3193 & 0.6205 & 8.8247 & -0.2229 & 0.2717 \\
\hline Colombia & 26.020 & 4.922 & 77.041 & 0.0017 & 0.4103 & -1.0724 & 18.2424 & -0.3987 & 0.4224 \\
\hline Finland & 16.1164 & 7.400 & 38.745 & -0.0009 & 0.3047 & -0.4185 & & -0.1756 & 0.1250 \\
\hline France & 20.212 & 8.877 & 36.545 & -0.0010 & 0.2659 & -0.3420 & 10.3162 & -0.2437 & 0.2322 \\
\hline Germany & 18.896 & 10.255 & 29.217 & -0.0006 & 0.2538 & -0.6685 & 8.2174 & -0.2380 & 0.1502 \\
\hline Hong & 15.355 & 8.488 & 31.158 & -0.0002 & 0.2882 & -1.2641 & 16.1666 & -0.2619 & 0.2074 \\
\hline Indi & 20.676 & 10.918 & 41.826 & 0.0006 & 0.2375 & -0.5312 & 5.7043 & -0.1866 & 0.1381 \\
\hline Ireland & 11.120 & 3.221 & 21.485 & 0.0001 & 0.3208 & -0.7462 & 14.3632 & -0.3756 & 0.2694 \\
\hline Israel & 22.179 & 11.573 & 36.074 & -0.0003 & 0.2378 & -0.0911 & 5.8980 & -0.1330 & 0.1631 \\
\hline Italy & 14.684 & 5.473 & 31.300 & 0.0000 & 0.4308 & -0.7082 & 35.5276 & -0.5159 & 0.4642 \\
\hline Japan & 51.161 & 13.270 & 171.782 & -0.0018 & 0.3151 & 0.7001 & 21.0139 & -0.2853 & 0.3886 \\
\hline Malaysia & 20.441 & 12.183 & 29.629 & -0.0002 & 0.1555 & -0.5547 & 6.3291 & -0.1115 & 0.0799 \\
\hline Mexico & 17.983 & 8.309 & 31.458 & 0.0008 & 0.2849 & -0.7697 & 12.8277 & -0.3051 & 0.2255 \\
\hline Netherlands & 15.453 & 7.823 & 25.926 & 0.0004 & 0.2606 & -0.7497 & 10.2093 & -0.2919 & 0.1449 \\
\hline Norway & 15.622 & 7.691 & 29.675 & -0.0001 & 0.2970 & -0.7442 & 8.0652 & -0.2459 & 0.1834 \\
\hline Peru & 14.760 & 4.660 & 29.632 & 0.0016 & 0.3183 & -0.4704 & 8.3147 & -0.2930 & 0.2577 \\
\hline Philippines & 20.843 & 9.319 & & 0.0013 & 0.3834 & & & -0.4026 & 0.4369 \\
\hline & 15.6691 & 7.804 & 29.515 & 0.0000 & 0.2451 & -0.2492 & 5.3329 & -0.1650 & 0.1608 \\
\hline Portugal & 13.888 & 6.801 & 24.761 & -0.0007 & 0.2305 & -1.2951 & 12.2555 & -0.2647 & 0.1441 \\
\hline Russia & & 0.039 & & 0.0036 & 1.4479 & 8.1806 & 150.2212 & -1.7843 & 3.2509 \\
\hline South Africa & 16.072 & 9.763 & 23.234 & 0.0003 & 0.2099 & -0.0541 & 6.2787 & -0.1163 & 0.1630 \\
\hline South Korea & 17.052 & 7.759 & 41.279 & -0.0016 & 0.2798 & -0.6531 & 7.3192 & -0.2189 & 0.1902 \\
\hline Spain & 12.637 & 5.426 & 23.570 & -0.0006 & 0.6122 & -1.2237 & 60.4374 & -0.7864 & 0.7048 \\
\hline Sweden & 18.872 & 10.332 & 31.429 & -0.0004 & 0.2443 & -0.7297 & 7.7379 & -0.2261 & 0.1287 \\
\hline Switzerland & 20.646 & 12.807 & 29.328 & 0.0000 & 0.2260 & -1.0579 & 12.0801 & -0.2370 & 0.1568 \\
\hline Taiwan & 19.210 & 9.5868 & 26.693 & -0.0001 & 0.2325 & -0.1121 & 5.3047 & -0.1140 & 0.1691 \\
\hline U.K. & 19.439 & 10.995 & 30.006 & -0.0006 & 0.2068 & -0.3965 & 14.5088 & -0.2332 & 0.2054 \\
\hline USA & 18.703 & 9.474 & 24.965 & -0.0001 & 0.1827 & -0.7277 & 10.4383 & -0.2012 & 0.1148 \\
\hline
\end{tabular}

Note: This table reports the descriptive statistics for CAPE. Panel A captures the properties of the CAPE levels while Panel B captures log-returns based on CAPE for 34 countries observed at weekly frequency. Std. stands for the standard deviation expressed in annualized terms. 


\section{References}

Asness, C. S., Moskowitz, T. J., Pedersen, L. H., 2013. Value and momentum everywhere. The Journal of Finance 68 (3), 929-985.

Bekaert, G., Wu, G., 2000. Asymmetric volatility and risk in equity markets. Review of Financial Studies 13 (1), 1-42.

Black, F., 1976. Studies in stock price volatility changes. Proceedings of the 1976 buisness meeting of the buisness and economics statistics section, American Statistical Association, $177-181$.

Bollerslev, T., 1990. Modelling the coherence in short run nominal exchange rates: A multivariate generalized arch approach. Review of Economic Studies 72, 498-505.

Bollerslev, T., Chou, R. Y., Kroner, K. F., 1992. Arch modeling in finance: A review of the theory and empirical evidence. Journal of Econometrics 52 (1), 5-59.

Campbell, J., Shiller, R., 1987. Stock prices, earnings and expected dividends. The Journal of Finance 43 (3), 661-676.

Cappiello, L., Engle, R. F., Sheppard, K., 2006. Asymmetric dynamics in the correlations of global equity and bond returns. Journal of Financial econometrics 4 (4), 537-572.

Christie, A. A., 1982. The stochastic behavior of common stock variances: value, leverage and interest rate effects. Journal of financial Economics 10 (4), 407-432.

Cronqvist, H., Siegel, S., Yu, F., 2015. Value versus growth investing: Why do different investors have different styles? Journal of Financial Economics.

Ding, Z., Engle, R. F., 2001. Large scale conditional covariance matrix modeling, estimation and testing. NYU working paper (Fin-01-029).

Engle, R., 2002. Dynamic conditional correlation: A simple class of multivariate generalized autoregressive conditional heteroskedasticity models. Journal of Business \& Economic Statistics 20 (3), 339-350. 
Gray, W. R., Carlisle, T. E., 2012. Quantitative Value: A Practitioner's Guide to Automating Intelligent Investment and Eliminating Behavioral Errors. John Wiley \& Sons.

Molodovsky, N., 1995. A theory of price-earnings ratios. Financial Analysts Journal 51 (1), $29-43$.

Piotroski, J. D., 2000. Value investing: The use of historical financial statement information to separate winners from losers. Journal of Accounting Research, 1-41.

Van der Hart, J., Slagter, E., Van Dijk, D., 2003. Stock selection strategies in emerging markets. Journal of Empirical Finance 10 (1), 105-132. 


\begin{abstract}
Abstrakt
Podíl mezi cenou akcie a současným výnosem na akcii je široce používaným měřítkem pro oceňování hodnoty akcií. Mnohem přesnější indikátor může být zkonstruován za použití stálých výnosů, tzv. cyklicky upravený podíl mezi cenou akcie a současným výnosem na akcii, CAPE, který zachycuje zisk společnosti v průměru během delšího období. V této studii se zaměřujeme na dynamiku oceňovacích měr napříč globálními trhy za použití jak rozvinutých tak i rozvíjejících se ekonomik. Používáme časově proměnný model DCC pro popis časové dynamiky korelací mezi CAPE pro 34 zemí a hlavním akciovým indexem daného regionu. Rozdíl v hodnotě např́ič trhy je statisticky významný během krize v roce 2008. Tento signál může být použit pro lepší rozložení akciového portfolia, jelikož umožňuje identifkovat společné trendy ve vývoji hodnoty. Toto je potvrzeno naší analýzou, která ukazuje výrazná období pod-nadhodnocení. V neposlední řadě naše simulace ukazují, že model může poskytnout signál včasného varování pro detekci špatné oceněných akcií na globální škále, které bývá spojeno s formováním bublin.
\end{abstract}




\section{Working Paper Series}

ISSN 1211-3298

Registration No. (Ministry of Culture): E 19443

Individual researchers, as well as the on-line and printed versions of the CERGE-EI Working Papers (including their dissemination) were supported from institutional support RVO 67985998 from Economics Institute of the ASCR, v. v. i.

Specific research support and/or other grants the researchers/publications benefited from are acknowledged at the beginning of the Paper.

(c) Mayank Gupta and Jan Novotný, 2016

All rights reserved. No part of this publication may be reproduced, stored in a retrieval system or transmitted in any form or by any means, electronic, mechanical or photocopying, recording, or otherwise without the prior permission of the publisher.

Published by

Charles University in Prague, Center for Economic Research and Graduate Education (CERGE) and

Economics Institute of the CAS, v. v. i. (EI)

CERGE-El, Politických vězňů 7, 11121 Prague 1, tel.: +420 224005 153, Czech Republic.

Printed by CERGE-EI, Prague

Subscription: CERGE-EI homepage: http://www.cerge-ei.cz

Phone: + 420224005153

Email: office@cerge-ei.cz

Web: http://www.cerge-ei.cz

Editor: Jan Zápal

The paper is available online at http://www.cerge-ei.cz/publications/working_papers/.

ISBN 978-80-7343-367-3 (Univerzita Karlova v Praze, Centrum pro ekonomický výzkum a doktorské studium)

ISBN 978-80-7344-373-3 (Národohospodářský ústav AV ČR, v. v. i.) 
CERGE-EI

P.O.BOX 882

Politických vězňů 7

11121 Praha 1

Czech Republic http://www.cerge-ei.cz 